\title{
ANALISIS PENGARUH RETURN ON ASSET (ROA) DAN NET PROFIT MARGIN (NPM) TERHADAP INCOME SMOOTHING (Studi Kasus Perusahaan Manufaktur yang terdaftar di BEI)
}

\author{
Iswandir \\ iswandir11@gmail.com
}

\begin{abstract}
ABSTRACK
Company value can increase through financial performance, and performance is an important indicator to attract investors. Good performance is the greater the company's ability to provide returns as per investor expectations. One of the ratios used in assessing financial performance is Return on Assets (ROA) and Net Profit Margin (NPM). The effects of investor relations and management, causing an asymmetric relationship, management with high bonus expectations by increasing the company's earnings in a certain period

Regardless of the legal or non-legal profit, Management has the freedom to change one method to another. The ability to use accounting techniques in records has been proven to be misused by management to make income smoothing.

There is an indication of income smoothing in manufacturing companies listed on the BEI, because of 53 companies studied 21 companies do practice income smoothing, only ROA variables that significantly partially affect the income smoothing, while the variable Net profit margin does not significantly influence partially to the alignment profit

Keyword; Return on Assets, Net Profit Margin, Income smooting
\end{abstract}

\section{PENDAHULUAN}

\subsection{Latar Belakang Masalah}

Laporan keuangan adalah produk dari akuntansi yang merupakan iktisar dari proses pencatatan transaksi-transaksi keuangan selama periode buku yang bersangkutan dan digunakan oleh pihakpihak yang berkepentingan untuk mengambil keputusan, pihak-pihak yang berkepetingan tersebut terdiri dari pihak internal dan juga pihak eksternal. Laporan keuangan memberikan informasi akan sumber daya entitas sehingga ketika di-sajikan laporan keuangan selayaknya harus dapat dipahami, relevan, andal, dapat dibandingkan, dan cerminan kondisi perusahaan pada masa lalu dan juga dapat dijadikan sebagai proyeksi ke masa akan datang.
Laporan keuangan dapat berfungsi sebagai alat untuk menilai bagaimana perusahaan dijalankan dan berkembang, kinerja manajemen dapat dilihat oleh investor sehingga mereka yakin atau tidak dengan dana yang telah dikucurkan, informasi keuangan bisa memberikan analisa bagaimana manajemen mengembangkan dana investasi tersebut sehingga memberikan imbal balik laba kepada investor. Jika implikasinya memburuk atau merugi, maka investor bisa saja menahan diri atau menjual seluruh kepemilikannya diperusahaan.

Dengan demikian investor wajib menganalisa laporan keuangan perusahaan, angka-angka yang tersaji dalam laporan keuangan merupakan reverensi untuk 
berspekulasi terhadap apa yang akan terjadi dikemudian hari. Investor tentunya mengharapkan retur dari investasi yang secepat mungkin dengan imbal positif yang relative tinggi, realtif dalam artian secara terus-menerus berkembang dimasa akan datang, bukanlah sesaat dalam artian spekulan.

Undang-Undang No.8 Tahun 1995 berisi tentang pasar modal dan peraturan lain menyatakan bahwa perusahaan publik atau emiten harus menyampaikan laporan keuangan tahunan yang telah diaudit dan laporan keuangan semi tahunan yang telah diaudit, dalam teori Sinyal (Signaling Theory) "perusahaan yang berkualitas baik dengan sengaja akan memberikan sinyal pada pasar, dengan demikian pasar diharapkan dapat membedakan perusahaan yg berkualitas baik dan buruk. Agar sinyal tersebut efektif, maka harus dapat ditangkap pasar \& dipersepsikan baik serta tidak mudah ditiru oleh perusahaan yang berkualitas buruk. Issuer dan underwriter (rational agent) dengan sengaja akan memberikan sinyal pada pasar. Jika perusahaan mampu menunjukkan kualitas perusahaan yang baik maka diharapkan ketidakpastian berkurang, suatu pengamatan mengenai pergerakan harga saham dipasar modal untuk mengetahui apakah ada abnormal return yang diperoleh pemegang saham akibat dari suatu peristiwa tertentu (Peterson, 1989), bertujuan mengukur hubungan antara suatu peristiwa yang mempengaruhi surat berharga dan pendapatan (return) dari surat berharga tersebut. Beaver (1968) dalam Bandi dan Jogiyanto (2000) yang mengamati reaksi investor atas publikasi laba saham biasa di sekitar tanggal publikasi. Pengujian kandungan informasi atas publikasi laporan laba tahunan ini menemukan bukti bahwa pengumuman laba menyebabkan abnormal stock price performance dan unexpected trading volume. Husnan et al. (1996) dalam Yudha (2005) meneliti dampak laporan keuangan terhadap kegiatan perdagangan saham dan variabilitas tingkat keuntungan. Hasil penelitian tersebut menunjukkan bahwa pada tanggal pengumuman laporan keuangan, kegiatan perdagangan maupun variabilitas tingkat keuntungan lebih tinggi dibandingkan dengan periode di luar tanggal pengumuman. Dengan demikian suatu informasi dikatakan relevan bagi investor jika informasi tersebut mampu mempengaruhi keputusan investor untuk melakukan transaksi di pasar modal yang tercermin pada perubahan harga. Salah satu informasi yang dianggap relevan oleh para investor adalah laporan keuangan perusahaan. Jika pelaku pasar modal menggunakan laporan keuangan sebagai informasi yang relevan dalam pengambilan keputusan investasi, seharusnya laporan keuangan yang diumumkan pada publik mampu mempengaruhi harga sekuritas. Dengan kata lain, pasar bereaksi terhadap pengumuman laporan keuangan. Reaksi tersebut ditunjukkan dengan adanya perubahan harga dan volume perdagangan saham perusahaan. Laporan keuangan sebagai hasil akhir dari proses akuntansi memang dirancang untuk menyediakan kebutuhan informasi bagi calon investor, kreditur, dan pemakai eksternal lainnya untuk pengambilan keputusan investasi.

Nilai perusahaan dapat meningkat melalui kinerja keuangan, dan kinerja tersebut merupakan indicator penting untuk dapat 
menarik investor, Koesno (1990) dalam Resmi (2000) menyatakan salah satu factor penting yang mempengaruhi ekspektasi investor adalah kinerja keuangan, dengan kinerja yang baik semakin besar kemampuan perusahaan dalam memberkan memberikan pengembalian sesuai harapan investor. Salah satu rasio yang digunakan dalam menilai kinerja keuangan adalah Return on Asset (ROA), rasio ini membantu investor ataupun calon investor menganalisa net income terhadap total asset. Dan Net Profit Margin (NPM), rasio ini mengukur laba bersih perusahaan dibandingkan dengan penjualan.

Efek dari pihak investor dan manajemen, menimbulkan hubungan asimetris, dimana keinginan pihak yang satu dengan yang lain yang tidak sama dan saling berseberangan, manajemen dengan ekspektasi bonus yang tinggi dengan meningkatkan laba perusahaan pada periode tertentu, sementara investor berusaha menurunkan laba dengan tujuan menarik saham kembali. Sehingga memunculkan pertanyaan apakah laporan keuangan yang disajikan manajemen menggambarkan keadaan perusahaan yang sebenarnya, apakah praktek perataan laba termasuk windows dressing.

\subsection{Rumusan Masalah}

Berdasarkan hubungan yang asimetris antara investor dan manajemen tersebut maka menjadikan rumusan masalah pada penelitian ini, dengan demikian dapat di sarikan detail poin penelitian sebagai berikut:

a. Apakah Return on Asset ada hubungannya dengan perataan
Laba pada perusahaan manufaktur yang terdaftar di BEI?

b. Apakah Net Profit Margin ada hubungannya dengan Perataan Laba pada perusahaan manufaktur yang terdaftar di BEI?

c. Apakah Return on Assets dan Net Profit Margin ada hubungannya dengan Perataan Laba pada perusahaan manufaktur yang terdaftar di BEI?

\subsection{Tujuan dan Manfaat Penelitian}

Berdasarkan dengan masalah di atas tujuan penelitian ini dapat disusun sebagai berikut:

a. Untuk mengetahui hubungan Return on Asset dengan perataan Laba pada perusahaan manufaktur yang terdaftar di BEI

b. Untuk mengetahui hubungan Net Profit Margin dengan Perataan Laba pada perusahaan manufaktur yang terdaftar di BEI

c. Untuk mengetahui hubungan Return on Asset dan Net Profit Margin secara bersama-sama terhadap Perataan Laba pada perusahaan manufaktur yang terdaftar di BEI

\section{METODOLOGI PENELITIAN}

2.1. Metode Penelitian

Penelitian ini dilakukan dengan metode deskriptif kuantitatif, dimana peneliti berusaha mengumpulkan dan menyajikan data dari perusahaan untuk dinalisis sehingga memberikan gambaran yang cukup jelas tentang objek yang diteliti. Data yang dianalisis adalah data laporan keuangan perusahaan manufaktur yang terdaftar di Bursa Efek Indonesia (BEI) tahun 2013 - 2016, mem- 
bandingkan dengan teori yang ada untuk dianalisa penerapannya terhadap tujuan penelitian.

\subsection{Deskripsi Data}

Return on Assets dan Net Profit Margin diperoleh langsung dari ringkasan laporan keuangan perusahan, Perataan laba menggunakan indeks eckel dimana identifikasi laporan keuangan perusahaan yang termasuk perata laba dan bukan perata laba, perusahaan dapat dikatakan perata laba jika koefisien variasi dari penjualan bersihnya lebih besar dari koefisien variasi dari perubahan laba.

\subsection{Teknik Analisi Data}

Jenis data yang digunakan adalah data sekunder berupa laporan keuangan perusahaan manufaktur yang terdaftar di BEI tahun pembukuan 2013 sampai dengan tahun 2016

Rumus untuk menghitung Return on Assets adalah:

$$
\text { ROA }=\frac{\text { Laba bersih }}{\text { Total Aktiva }}
$$

Rumus untuk menghitung Net Profit Margin adalah:

$$
\mathrm{NPM}=\frac{\text { Laba bersih }}{\text { Penjualan }} \times 100 \%
$$

Rumus untuk menghitung perataan laba adalah:

$\mathrm{CV} \Delta \mathrm{S}$ atau $\mathrm{CV} \Delta \mathrm{I} \sqrt{\frac{\sum(\Delta \mathrm{x}-\Delta \dot{x}) 2}{n-1}}: \Delta \dot{x}$

$$
\begin{array}{ll}
\mathrm{CV} & =\text { Koefisien variasi } \\
\Delta \mathrm{S} & =\text { Perubahan Penjualan } \\
\Delta \mathrm{S} & =\text { Perubahan Laba } \\
\mathrm{Ax} & =\text { Perubahan LAba (I) atau } \\
& \text { Penjualan (s) } \\
\mathrm{A} \dot{x} & =\begin{array}{l}
\text { Rata-rata perubahan laba } \\
\text { atau penjualan }
\end{array}
\end{array}
$$

\subsection{Tinjauan Teoritis}

\section{a. Laporan Keuangan}

Laporan keuangan bertujuan untuk menyediakan informasi yang menyangkut posisi keuangan, kinerja serta perubahan posisi keuangan suatu perusahaan yang bermanfaat bagi sejumlah besar pemakai dalam pengambilan keputusan ekonomi. Munawir (2005:5) yang menyatakan bahwa laporan keuangan adalah daftar yang disusun akuntan pada akhir periode untuk satu perusahaan. Kedua daftar ini adalah daftar neraca atas daftar rugi-laba.

1) Tujuan Laporan Keuangan

Menurut AICPA dalam

Harahap (2010:133) tujuan laporan keuangan dibagi menjadi:

a) Tujuan umum Menyajikan laporan posisi keuangan, hasil usaha, dan perubahan keuangan secara wajar sesuai prinsip akuntansi yang diterima.

b) Tujuan Khusus Memberikan informasi tentang kekayaan, kewajiban, kekayaan bersih, proyeksi laba, perubahan kekayaan 
dan kewajiban, serta informasi lainnya yang relevan.

2) Karakteristik Laporan Keuangan

IAI (2004:7) ada empat karakteristik kualitatif pokok laporan keuangan, yaitu:

a) Dapat dipahami.

Pemakai diasumsikan memiliki pengetahuan yang memadai tentang aktivitas ekonomi dan bisnis, akuntansi serta kemauan untuk mempelajari informasi dengan ketentuan yang wajar.

b) Relevan.

Informasi harus relevan untuk memenuhi kebutuhan para pemakai dalam proses pengambilan keputusan. Informasi memiliki kualitas relevan apabila informasi tersebut dapat mempengaruhi keputusan ekonomi pemakai dengan membantu mereka mengevaluasi peristiwa masa lalu, masa kini atau masa depan, menegaskan atau mengkoreksi, hasil evaluasi mereka di masa lalu.

c) Keandalan.

Informasi memilki kualitas andal jika bebas dari pengertian menyesatkan, kesalahan material, dan dapat diandalkan pemakainya sebagai penyajian yang tulus atau jujur dari yang seharusnya disajikan atau yang secara wajar diharapkan untuk disajikan. d) Dapat dibandingkan. Pemakai laporan keuangan harus dapat memperbandingkan laporan keuangan perusahaan antar periode untuk mengidentifikasi kecenderungan posisi keuangan dan kinerja perusahaan. Selain itu juga pemakai harus dapat memperbandingkan laporan keuangan antar perusahaan untuk mengevaluasi posisi keuangan, kinerja serta perubahan posisi keuangan secara relatif.

3) Pengguna Laporan Keuangan Pengguna laporan keuangan meliputi para investor dan calon investor, kreditor (pemberi pinjaman, pemasok, kreditur usaha lainya, pelanggan, pemerintah dan lembaga lainnya, karyawan dan masyarakat, dan shareholders (para pemegang saham). Para pemakai laporan keuangan ini menggunakan laporan keuangan untuk memenuhi beberapa kebutuhan informasi yang berbeda, Harahap $(2010 ; 120)$

4) Jenis-Jenis Laporan Keuangan

IAI, (2007:2) menyatakan "laporan keuangan yang lengkap terdiri atas komponen-komponen berikut ini: neraca, laporan laba rugi, laporan perubahan ekuitas, laporan arus kas dan catatan atas laporan keuangan." 
a) Neraca (Balance Sheet) Menurut Munawir (2002: 13) Neraca adalah laporan yang sistematis tentang aktiva, hutang serta modal dari suatu perusahaan pada suatu saat tertentu, tujuan neraca adalah untuk menunjukkan posisi keuangan suatu perusahaan pada suatu tanggal tertentu.

b) Laporan Laba Rugi (Income Statement)

Laporan rugi laba disusun dengan maksud untuk menggambarkan hasil operasi yang diperoleh perusahaan selama periode tertentu. Menurut Rudianto (2009:15) suatu laporan yang menunjukkan kemampuan perusahaan dalam menghasilkan keuntungan dalam suatu periode akuntansi atau satu tahun.

c) Laporan Perubahan Ekuitas (Statement of Owner's Equity)

Menurut Rudianto (2009: 16) adalah laporan yang menunjukkan peruba-han modal pemilik atau laba yang tidak dibandingkan dalam suatu periode akuntansi akibat transaksi usaha selama periode tersebut.

d) Laporan Arus Kas

Menurut Kasmir (2012:29) laporan arus kas adalah merupakan laporan yang menunjukkan semua aspek yang berkaitan dengan kegiatan perusahaan, baik yang berpengaruh langsung atau tidak terhadap kas. Informasi arus kas berguna untuk menilai kemampuan perusahaan dalam menghasilkan kas dan setara kas dan memungkinkan para pemakai mengembangkan model untuk menilai dan membandingkan nilai sekarang dari arus kas masa depan (future cash flow) dari berbagai perusahaan.

e) Catatan Atas Laporan Keuangan

Catatan atas laporan keuangan harus disajikan secara sistematis. Setiap pos dalam neraca, laporan laba rugi dan laporan arus kas harus berkaitan dengan informasi yang terdapat pada catatan atas laporan keuangan.

\section{b. Return on Assets (ROA)}

Return on Assets (ROA) merupakan salah satu rasio profitabilitas. Dalam analisis laporan keuangan, rasio ini paling sering disoroti, karena mampu menunjukkan keberhasilan perusahaan menghasilkan keuntungan. ROA mampu mengukur kemampuan perusahaan menghasilkan keuntungan pada masa lampau untuk kemudian diproyeksikan di masa yang akan datang. Assets atau aktiva yang dimaksud adalah keseluruhan harta perusahaan, yang diperoleh dari modal sendiri maupun dari 
modal asing yang telah diubah perusahaan menjadi aktivaaktiva perusahaan yang digunakan untuk kelangsungan hidup perusahaan.

Menurut Brigham dan Houston (2001:90), "Rasio laba bersih terhadap total aktiva mengukur pengembalian atas total aktiva (ROA) setelah bunga dan pajak".

Menurut Horne dan Wachowicz (2005:235), "ROA mengukur efektivitas keseluruhan dalam menghasilkan laba melalui aktiva yang tersedia; daya untuk menghasilkan laba dari modal yang diinvestasikan".

Horne dan Wachowicz menghitung ROA dengan menggunakan rumus laba bersih setelah pajak dibagi dengan total aktiva.

Bambang Riyanto (2001:336) menyebut istilah ROA dengan Net Earning Power Ratio (Rate of Return on Investment / ROI) yaitu kemampuan dari modal yang diinvestasikan dalam keseluruhan aktiva untuk menghasilkan keuntungan neto. Keuntungan neto yang beliau maksud adalah keuntungan neto sesudah pajak. Dari uraian di atas dapat disimpulkan bahwa ROA atau ROI dalam penelitian ini adalah mengukur perbandingan antara laba bersih setelah dikurangi beban bunga dan pajak (Earning After Taxes / EAT) yang dihasilkan dari kegiatan pokok perusahaan dengan total aktiva (assets) yang dimiliki perusahaan untuk melakukan aktivitas perusahaan secara keseluruhan dan dinyatakan dalam persentase.

1) Perhitungan Return on Assets Menurut Brigham dan Houston (2001), pengembalian atas total aktiva (ROA) dihitung dengan cara membandingkan laba bersih dengan total aktiva.

Laba bersih (net income) merupakan ukuran pokok keseluruhan keberhasilan perusahaan. Laba dapat mempengaruhi kemampuan perusahaan untuk mendapat pinjaman dan pendanaan ekuitas, posisi likuiditas perusahaan dan kemampuan perusahaan untuk berubah. Jumlah keuntungan (laba) yang diperoleh secara teratur serta kecenderungan atau trend keuntungan yang meningkat merupakan suatu faktor yang sangat penting yang perlu mendapat perhatian penganalisa di dalam menilai profitabilitas suatu perusahaan. Munawir (2001:57) menjelaskan bahwa profitabilitas atau rentabilitas digunakan untuk mengukur efisiensi penggunaan modal dalam suatu perusahaan dengan memperbandingkan antara laba dengan modal yang digunakan dalam operasi, oleh karena itu keuntungan yang besar tidak 
menjamin atau bukan merupakan ukuran bahwa perusahaan itu rentable. Bagi manajemen atau pihak-pihak yang lain, rentabilitas yang tinggi lebih penting daripada keuntungan yang besar.

Semakin besar nilai ROA, menunjukkan kinerja perusahaan yang semakin baik pula, karena tingkat pengembalian investasi semakin besar. "Nilai ini mencerminkan pengembalian perusahaan dari seluruh aktiva (atau pendanaan) yang diberikan pada perusahaan" (Wild, Subramanyam, dan Halsey, 2005:65).

2) Kelebihan dan Kelemahan Return on Assets

a) Kelebihan ROA diantaranya sebagai berikut:

○ ROA mudah dihitung dan dipahami.

- Merupakan alat pengukur prestasi manajemen yang sensitive terhadap setiap pengaruh keadaan keuangan perusahaan.

- Manajemen menitikberatkan perhatiannya pada perolehan laba yang maksimal.

- Sebagai tolok ukur prestasi manajemen dalam memanfaatkan assets yang dimiliki perusahaan untuk memperoleh laba.
- Mendorong tercapainya tujuan perusahaan.

- Sebagai alat mengevaluasi atas penerapan kebijakan-kebijakan manajemen.

b) kelemahan di antaranya:

o Kurang mendorong manajemen untuk menambah assets apabila nilai ROA yang diharapkan ternyata terlalu tinggi.

- Manajemen cenderung fokus pada tujuan jangka pendek bukan pada tujuan jangka panjang, sehingga cenderung mengambil keputusan jangka pendek yang lebih menguntungkan tetapi berakibat negatif dalam jangka panjangnya.

- ROA mengandung distorsi yang cukup besar terutama dalam kondisi inflasi.

Tinggi rendahnya ROA tergantung pada pengelolaan aset perusahaan oleh manajemen yang menggambarkan efisiensi dari operasional perusahaan. Semakin tinggi ROA semakin efisien perusahaan dan begitu juga sebaliknya. Rendahnya ROA disebabkan oleh banyaknya aset yang menganggur, investasi persediaan yang terlalu banyak, aktiva tetap beroperasi dibawah normal dan lain-lain. 


\section{c. Net Profit Margin (NPM)}

Adalah rasio yang digunakan untuk menunjukkan kemampuan perusahaan dalam menghasilkan keuntungan bersih. Menurut Bastian dan Suhardjono (2006), Net Profit Margin adalah perbandingan antara laba bersih dengan penjualan. Rasio ini sangat penting bagi manajer operasi karena mencerminkan strategi penetapan harga penjualan yang diterapkan perusahaan dan kemampuannya untuk mengendalikan beban usaha. Menurut Weston dan Copeland (1998), semakin besar Net Profit Margin berarti semakin efisien perusahaan tersebut dalam mengeluarkan biaya-biaya sehubungan dengan kegiatan operasinya.

Semakin besar NPM, maka kinerja perusahaan akan semakin produktif, sehingga akan meningkatkan kepercayaan investor untuk menanamkan modalnya pada perusahaan tersebut. Rasio ini menunjukkan berapa besar persentase laba bersih yang diperoleh dari setiap penjualan. Semakin besar rasio ini, maka dianggap semakin baik kemampuan perusahaan untuk mendapatkan laba yang tinggi. Hubungan antara laba bersih dan penjualan bersih menunjukkan kemampuan manajemen dalam menjalankan perusahaan secara cukup berhasil untuk menyisakan margin tertentu sebagai kompensasi yang wajar bagi pemilik yang telah menyediakan modalnya untuk suatu risiko. Para investor pasar modal perlu mengetahui kemampuan perusahaan untuk menghasilkan laba. Dengan mengetahui hal tersebut investor dapat menilai apakah perusahaan itu profitable atau tidak. Menurut Sulistyanto (tanpa tahun: 7) angka NPM dapat dikatakan baik apabila $>5$ $\%$.

\section{d. Perataan Laba (income smooting)}

Ada kecendrungan para pemakai laporan keuangan untuk lebih memperhatikan laba yang terdapat pada laporan laba-rugi seperti yang dikemukakan oleh banyak peneliti diantaranya Ball and Brown, 1968; Beaver et al, 1968; Ohlson and Ahroff, 1992 dalam Jurnal Riset Akuntansi Indonesia (JRAI) 1998 yang ditulis Liaw She Jin dalam Ariyani (2004). Selain itu manajer juga dinilai kinerjanya berdasarkan atas informasi tersebut, sehingga hal ini memacu timbulnya perilaku yang tidak sesuai (dysfunctional behavior). Perilaku yang tidak sesuai tersebut digunakan oleh para manajer untuk memanipulasi laba guna meningkatkan kinerja perusahaan (Ji dan Machfoedz, 1998).

Deteksi atas kemungkinan dilakukannya manipulasi laba atau yang disebut juga dengan 
manajemen laba (earning management) dalam laporan keuangan diteliti melalui penggunaan akrual. Jumlah akrual yang tercermin dalam penghitungan laba terdiri dari discretionary dan nodiscretionary. Transaksi nodiscretionary merupakan transaski yang dicatat dengan menggunakan satu prosedur dan apabila prosedur tersebut dipilih maka manajemen diharapkan konsisten dalam menggunakan prosedur tersebut. Contoh dari transaksi ini adalah metode penentuan harga pokok persediaan dan metode penyusutan. Sebaliknya transaksi discreteonary memberikan kebebasan kepada manajemen menentukan jumlah transaksi akrual secara fleksibel. Contohnya seperti penentuan cadangan kerugian piutang yang berasal dari manajemen laba yang dilakukan manajer.

Diskresi manajerial tersebut dapat meningkatkan kandungan informasi laba karena memungkinkan adanya pengkomunikasian informasi privat. Penggunaan discretionary seperti ini disebut efficient earning management (EEM). Di lain pihak, adannya ketidaksamaan insentif antara manajer dan pemegang saham dapat menyebabkan manajer menggunakan fleksibilitas yang diperbolehkan dalam pernyataan akuntansi yang berlaku umum untuk melakukan earning management secara oportunistik, sehingga menciptakan distorsi dalam laba yang dilaporkan. Hal ini disebut opportunistic earnings management (OEM) (Sylvia dan Yanivi, 2003).

Kebijakan akrual ini oleh manajer perlu diungkapkan dalam laporan keuangan. Pengungkapan (disclosure) dalam laporan keuangan, dalam bentuk catatan atas laporan keuangan digunakan untuk memperkecil gap antara manajemen sebagai penyusun laporan dengan pihak luar yang menggunakan laporan keuangan.

\section{1) Manajemen Laba dan Perataan Laba}

Menurut Scoot (2000) dalam Dewi (2001) Manajemen laba merupakan cara yang digunakan oleh manajemen untuk mempengaruhi angka laba secara sistematis dan sengaja dengan cara memilih kebijakan akuntansi dan prosedur akuntansi tertentu dengan tujuan memaksimalkan utility manajemen dan harga saham. Manajemen laba menjadi suatu hal yang tidak baik dilakukan karena informasi laporan keuangan yang disajikan berkurang reliabilitasnya, sehingga dikuatirkan akan berakibat pada pengambilan keputusan yang keliru.

Manajemen laba mencakup dua bentuk utama yaitu yang 
pertama manajemen melakukan upaya perataan laba (Income Smoothing) untuk setiap periode dan yang kedua manajemen melakukan upaya peningkatan (Pemaksimalan) atau penurunan (peminimalan) laba dalam suatu periode. Barnea et al (1976) dalam Dwiatmini dan Nurcolis (2001) mendefenisikan perataan laba sebagai pengurangan yang disengaja terhadap fluktuasi pada beberapa level laba supaya dianggap normal bagi perusahaan. Defenisi perataan laba menurut Beildman (1973) adalah suatu usaha yang dilakukan manajemen untuk menekan variasi dalam laba sejauh yang dimungkinkan oleh prinsip akuntansi.

Koch (1981) dalam Hermawan (1998) yang dikutip Ariyani (2004) menyatakan bahwa perataan laba merupakan alat yang digunakan oleh manajemen untuk mengurangi besarnya variabilitas pendapatan atau laba yang dilaporkan untuk tujuan tertentu dengan cara memanipulasi variable artifical (akuntansi) atau variable real (transaksi). Sofyan Syafri dalam bukunya yang berjudul Analisa Kritis Atas Laporan Keuangan, menyatakan bahwa praktik perataan laba adalah upaya menstabilkan laba dimana tidak banyak variance dari satu periode ke periode lain sehingga dinilai sebagai prestasi baik.

Menurut Hepworth (1953) yang didukung Ashari, dkk (1994) dan Zuhroh (1996) dalam Jatiningrum (2000), bahwa tindakan perataan laba merupakan tindakan yang logis dan rasional bagi manajer untuk meratakan laba dengan menggunakan cara atau metode akuntansi tertentu, alasannya antara lain pertama, rekayasa untuk mengurangi laba dan menaikkan biaya pada periode berjalan dapat mengurangi hutang pajak. Kedua, tindakan perataan laba dapat meningkatkan kepercayaan investor, karena mendukung kestabilan penghasilan dan kebijakan deviden sesuai dengan keinginan. Ketiga, tindakan perataan laba dapat mempererat hubungan antara manajer dan karyawan, karena dapat mengindari permintaan kenaikan upah/gaji oleh karyawan/pekerja. Dan keempat, tindakan perataan laba memiliki dampak psikologis pada perekonomian, dimana kemajuan dan kemunduran dapat dibandingkan dan gelombang optimisme dan pesimisme dapat ditekan.

Ditambahkan pula oleh Gordon (1964) dalam Jatiningrum (2000), bahwa 
perataan laba mempunyai peranan yang penting untuk mengurangi bias dari pemegang saham dalam memperhitungkan laba di masa lalu, yang digunakan untuk memprediksi laba di masa depan. Lebih lanjut, Lambert (1984) dan Dye (1988) dalam Jatiningrum (2000) dalam seting keagenan menyebutkan bahwa manajer yang mempunyai resiko menolak untuk terhindar dari hutang dan pinjaman di dalam pasar modal, memiliki daya dorong untuk melakukan tindakan perataan laba. Pendapat ini didukung oleh Trueman dan Tritman (1998) dalam Jatiningrum (2000) dalam seting market yang berhubungan dengan kreditor, menunjukkan bahwa manajer lebih menyukai alternatif yang menghasilkan aliran kas yang lebih merata.

\section{2) Faktor-Faktor Yang Mem-} pengaruhi Perataan Laba

Terdapat banyak faktor yang mungkin menentukan adanya praktik perataan laba. Ilmainir (1993) yang dikutip Kikky (2002) melakukan penelitian faktor-faktor pendorong perataan laba pada perusahaan di Indonesia dengan menggunakan sebanyak 15 sampel perusahaan yang terdaftar di BEJ. Hasilnya menunjukkan bahwa harga saham, perbedaan laba aktual dan laba normal, serta kebijakan akuntansi mengenai laba terbukti sebagai faktor yang mempengaruhi perataan laba.

Moses (1987), Albrecht dan Richardson (1990) dalam Ariyani (2004) membuktikan bahwa ukuran perusahaan, kelompok usaha (sektor Industri) menunjukkan adanya asosiasi dengan perataan laba. Tetapi Ashari (1994) Jin dan Machfoedz (1998), dan Priyo (2001) tidak membuktikan bahwa hal-hal tersebut sebagai faktor yang mempengaruhi perataan laba. Ilmainir (1993) seperti yang dikutip Kiky (2002) menunjukkan hasil yang sama yaitu tidak berpengaruhnya ukuran perusahaan terhadap perataan laba. Menurut pendapatnya, perbedaan ini kemungkinan disebabkan karena adanya perbedaan perlakuan pemerintah antara negara maju dan negara berkembang.

Sedangkan Archibald (1967), Carlson dan Chenchuramaiah (1997), Ashari (1994) dalam penelitiannya mereka membuktikan salah satu variabel diantaranya profitabilitas perusahaan yang merupakan faktor yang mempengaruhi perataan laba. Tetapi Zuhroh (1996), Jin dan Machfoedz (1998) tidak berhasil membuktikan profitabilitas, mereka hanya membuktikan 
bahwa leverage operasi adalah sebagai faktor yang berpengaruh terhadap praktik perataan laba yang dilakukan perusahaan di Indonesia. Sedangkan Jatiningrum (2000) mencoba menguji faktor sektor industri sebagai variabel penelitiannya, namun penelitiannya tidak berhasil menunjukkan bukti bahwa sektor industri merupakan faktor pendorong dilakukannya tindakan perataan laba. Hasil ini berbeda dengan hasil penelitian Ashari, dkk (1994). Hermawan (1997) dengan sampel perusahaan publik sektor industri manufaktur yang terdaftar di BEJ serta Priyo (2001) dalam penelitiannya dengan 313 sampel perusahaan di ASEAN, membuktikan ukuran perusahaan, dividen payout, debt equity ratio serta nasionalitas perusahaan sebagai faktor-faktor yang tidak mempengaruhi perataan laba. Ini berbeda dengan penelitian yang dilakukan oleh Deefond dan Jiambalvo (1994), Sweeney (1994) yang tidak membuktikan bahwa dividen payout ratio, debt equity ratio sebagai faktor yang mempengaruhi perataan laba.

White (1970), Moses (1987), Beattie (1993), dan Houilthausen (1995) seperti yang dikutip Salmawi dan Bambang Sudibyo (1999) dalam Ariyani (2004) meneliti tentang tujuan yang hendak dicapai dengan melakukan praktik perataan laba. Kikky (2002) melakukan penelitian tentang ada tidaknya perataan laba pada lembaga keuangan non bank dan faktor-faktor yang mempengaruhi perataan laba. Dari hasil penelitiannya tersebut terbukti bahwa ukuran perusahaan mempengaruhi praktik perataan laba, tetapi debt equity ratio serta profitabilitas tidak terbukti mempengaruhi perataan laba.

\section{3) Pendekatan yang Diguna- kan Dalam Perataan laba} Albercht dan Richarson (1999) menyatakan bahwa terdapat tiga pendekatan dalam studi yang berkaitan dengan perataan laba. Ketiga pendekatan tersebut adalah:

a) The classical approach. Pendekatan ini digunakan untuk menguji hubungan antara variabel-variabel yang dapat digunakan untuk melakukan penstabilan laba dan pengaruhnya terhadap laba yang dilaporkan.

b) The income variability approach. Pendekatan ini digunakan untuk membedakan tindakan/perilaku manajemen yang dapat menyebabkan timbulnya penstabilan laba secara artificial dengan peraturan 
yang bersiat real dan natural.

c) The dual economy approach. Pendekatan ini dilakukan dengan membandingkan perubahan laba operasi dan laba normal dengan perubahan-perubahan biaya pada perusahaan-perusahaan berdasarkan sektor-sektor tertentu (di Amerika Serikat terdapat 2 sektor yaitu core dan periphery sector). Core sector terdiri dari durabel manufacturing dan industri yang mengolah hasil alam. Peripheri sector terdiri dari industri pertanian, non durable manufacturing, dan industri eceran.

\section{4) Teknik perataan Laba}

Berbagai teknik yang digunakan dalam perataan laba diantaranya adalah sebagai berikut:

a) Perataan melalui waktu terjadinya transaksi atau pengakuan transaksi mellui kebijakan manajemen itu sendiri (accrual), misalnya: pengeluaran biaya riset dan pengembangan. Selain itu banyak juga perusahaan yang menerapkan kebijakan diskon dan kredit sehingga hal ini dapat menyebabkan meningkatnya jumlah piutang dan penjualan pada akhir bulan terakhir tiap kuarter, sehingga laba kelihatan stabil pada periode tertentu.

b) Perataan melalui alokasi untuk beberapa periode tertentu. Manajer memiliki kewenangan untuk mengalokasikan pendapatan dan atau beban untuk periode tertentu. Misalnya, jika penjulan meningkat maka manajemen dapat membebankan biaya riset dan penelitian serta amortisasi goodwill pada periode itu untuk mensabilkan laba.

c) Perataan melalui klasifikasi. Manajemen memiliki kewenangan dan kebijakan sendiri untuk mengklasifikasikan pospos rugi laba dalam kategori yang berbeda. Misalnya, jika pendapatan operasi sulit untuk didefenisikan maka manajer dapat mengklasifikasikan pos itu pada pendapatan operasi atau pendapatan non operasi. Dalam hal ini dapat digunakan sewaktuwaktu untuk meratakan laba melihat kondisi pendapatan periode itu.

Teknik-teknik itu memang mungkin untuk dilakukan karena Prinsip Akuntasi Berterima Umum (PABU) memberikan berbagai pilihan dalam mencatat berbagai peristiwa keuangan. Manajemen memiliki keleluasan untuk mengganti satu metode ke 
metode lain. Keleluasan untuk memakai teknik-teknik akuntansi dalam mencatat terbukti telah disalahgunakan oleh manajemen untuk melakukan perataan laba. Bahkan Koch (1981) mensinyalir bahwa perataan laba banyak dilakukan dengan mengunakan teknik-teknik akuntansi yaitu dengan merubah kebijakan akuntansi. (Sopa Sugiarto, 2003).

Koch (1981) Menyatakan bahwa peratan laba dapat dilakukan dengan dua cara yaitu:

a) Artificial smoothing, perataan laba yang mengacu pada prosedur akuntansi yang dimplementasikan dimana manajemen melakukan tindakan untuk mengakui biaya dan atau pendapatan dari satu periode ke periode lain (manipulasi melalui metode akuntansi).

b) Real smoothing, Perataan laba yang mengacu pada transaksi aktual yang dilakukan oleh entitas dimana manajemen mempunyai kendali terhadap transaksi yang akan mempengaruhi laba di masa depan (manipulasi melalui transaski).

\section{5) Sasaran Praktik Perataan Laba}

Adapun yang dapat dijadikan sebagi sasaran praktik peratan laba adalah aktivitas-aktivitas yang dapat digunakan oleh manajemen untuk mempengaruhi aliran data atau informasi. Untuk menciptakan laporan keuangan yang sesuai dengan keinginan manajemen, manejer dapat memasukkan informasi yang akan datang kedalam laporan periode ini atau sebaliknya (Priyo, 2001 dalam Ariyani, 2004).

Seperti yang dikutip dari Jin dan Machfoedz (1998) instrumen yang dapat digunakan dalam perataan laba antara lain adalah pendapatan, deviden, perubahan dalam kebijakan akuntansi, biaya pensiun, pos luar biasa, kredit pajak investasi, depresiasi dan biaya tetap, perubahan mata uang, klasifikasi akuntansi dan pencadangan.

Foster (1986) mengklasifiksikan unsur-unsur laporan keuangan yang dijadikan dalam praktik perataan laba, yaitu;

a) Unsur Penjualan

- Saat pembuatan faktur. Misalnya: penjualan yang sebenarnya untuk periode yang akan datang pembuatan fakturnya dilakukan pada periode ini dan dilapor- 
kan sebagai penjualan periode ini.

- Pembuatan pesanan atau penjulan fiktif.

- Downgrading

(penurunan) produk. Misalnya dengan cara mengklasifikasikan produk yang belum rusak kedalam kelompok produk yang rusak dan selanjutnya dilaporkan telah terjual dengan harga yang lebih rendah dari harga yang sebenarnya.

b) Unsur Biaya

- Memecah faktur. Misalnya faktur untuk sebuah pembelian/pesanan

dipecah menjadi beberapa pembelian/pesanan dan selanjutnya dibuatkan beberapa faktur dengan tanggal berbeda kemudian dilaporkan dalam beberapa periode akuntansi.

- Mencatat prepayment (biaya dibayar dimuka) sebagai biaya. Misalnya melaporkan biaya advertensi dibayar dimuka untuk tahun depan sebagai biaya advertensi tahun ini.

\section{HASIL PENELITIAN DAN PEMBAHASAN}

\subsection{Hasil Uji Statistik Deskriptif}

\begin{tabular}{|c|c|c|c|c|c|}
\hline Var. & $\mathbf{N}$ & Minimum & Maximum & Mean & $\begin{array}{c}\text { Std. } \\
\text { Deviation }\end{array}$ \\
\hline$R O A$ & 53 & $-0,0701$ & 0,6255 & 0,1271 & 0,1495 \\
\hline$N P M$ & 53 & 0,2 & 0,3 & 0,2487 & 0,2877 \\
\hline$P L$ & 53 & 0,1203 & 1,3135 & 0,5924 & 0,3486 \\
\hline
\end{tabular}

Kesimpulan;

Berdasarkan hasil pengujian statistik deskriptif terhadap perataan laba (Y) dapat diketahui bahwa nilai minimum rasio perataan laba sebesar 0,1202532. Nilai maksimum rasio perataan laba sebesar 1,3135228. Nilai rata-rata (mean) rasio perataan laba sebesar 0,592413504 dengan standar deviasi sebesar 0,3485634172 .

Berdasarkan hasil pengujian statistik deskriptif terhadap ROA $\left(\mathrm{X}_{1}\right)$ dapat diketahui bahwa nilai minimum ROA sebesar -0,0701206. Nilai maksimum ROA sebesar 0,6255156 . Nilai rata-rata (mean) arus ROA sebesar 0,127123259 dengan standar deviasi sebesar 0,1495124494 .

Berdasarkan hasil pengujian statistik deskriptif terhadap NPM $\left(\mathrm{X}_{2}\right)$ dapat diketahui bahwa nilai minimum NPM sebesar 0,2. Nilai maksimum NPM sebesar 0,3 Nilai ratarata (mean) NPM sebesar 0,248687719 dengan standar deviasi sebesar ,0287676113. 


\subsection{Hasil Uji Asumsi Klasik} Uji Normalitas

Uji normalitas digunakan untuk melihat apakah data telah ter-distribusi normal atau tidak. Uji normalitas dalam penelitian ini dilakukan dengan grafik Normal
Probability Plot, dan uji Kolmogorov-Smirnov.

Berdasarkan hasil pengolahan data dengan bantuan SPSS versi 21.0 diperoleh grafik Normal Probability Plot dan Kolmogorov-Sminov, sebagai berikut:

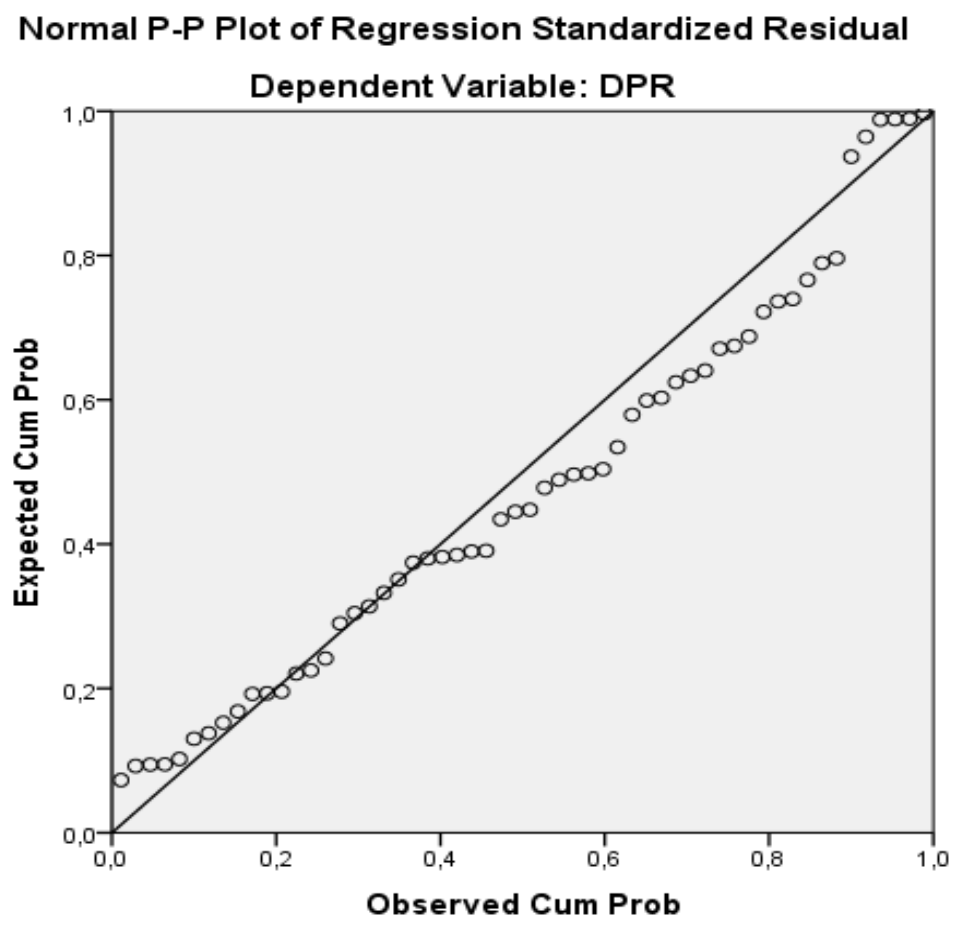

Kesimpulan;

Pengujian normalitas Normal Probability Plot memberikan hasil bahwa data (titik) menyebar di sekitar garis diagonal dan mengikuti arah garis diagonal. Hasil pengujian ini menyatakan bahwa data telah terdistribusi normal karena telah sesuai dengan kriteria penentuan normalitas data, yakni jika data menyebar di sekitar garis diagonal dan menunjukan pol distribusi normal, maka model regresi memenuhi asumsi normalitas. 
One-Sample Kolmogorov-Smirnov Test

\begin{tabular}{|ll|r|}
\hline & & $\begin{array}{r}\text { Unstandardiz } \\
\text { ed Residual }\end{array}$ \\
\hline $\mathrm{N}$ & Mean & 56 \\
Normal Parameters & Stb. &, 1780745 \\
& Deviation &, 15606062 \\
Most Extreme & Absolute &, 144 \\
Differences & Positive &, 144 \\
Kolmogorov-Smirnov Z Z &,- 128 \\
Asymp. Sig. (2-tailed) & Negative & 1,081 \\
\hline
\end{tabular}

a. Test distribution is Normal.

b. Calculated from data.

Sumber: Pengolahan data dengan SPSS 21.0

Nilai sign atas hasil pengujian normalitas dalam penelitin ini adalah sebesar 0,193. Jika melihat kriteria penentuan normalitas data di atas, data dalma penelitian ini telah terdistribusi normal karena nilai sign hitung $0,193>\alpha(0,05)$

\section{Uji Multikolinearitas}

Uji multikolinearitas bertujuan untuk menguji adanya korelasi antara variabel-variabel independen. Model regresi yang baik seharusnya

\begin{tabular}{|c|c|c|}
\hline $\begin{array}{c}\text { Variabel } \\
\text { Independen }\end{array}$ & \multicolumn{2}{|c|}{ Collinearity Statistics } \\
\cline { 2 - 3 } & Tolerance & VIF \\
\hline ROA & 0,968 & 1,033 \\
\hline$N P M$ & 0,936 & 1,068 \\
\hline
\end{tabular}

Sumber: Pengolahan data dengan SPSS 21.0

Berdasarkan tabel ringkasan pengujian multikolinearitas terhadap tidak terjadi korelasi diantara variabel independen. Kriteria penilaian didasarkan atas nilai tolerance dan nilai variance inflation factor (VIF). Bila nilai tolerance $>0,1$ atau nilai VIF $<10$, maka tidak terjadi multikolinearitas. Berdasarkan hasil pengolahan data dengan bantuan SPSS versi 21.0 diperoleh nilai tolerance dan nilai variance inflation factor (VIF), sebagai berikut:

variabel independen penelitian, nilai tolerance atas ROA dan NPM masing-masing sebesar 0,968 dan0,936 dengan nilai Variance Inflation Factor (VIF) sebesar 1,033, dan 1,068 . Karena nilai tolerance $>0,1$ dan nilai VIF $<10$, hal ini berarti variabel independen tersebut telah memenuhi kriteria pemenuhan uji multikolinearitas. 
Hasil Uji Hipotesis Penelitian

\begin{tabular}{|l|c|c|}
\hline & $\begin{array}{c}\text { HASIL UJI } \\
\text { HIPOTESIS }\end{array}$ & Sign \\
\hline ROA & $\mathrm{t}_{\text {hitung }}=7,615$ & 0,000 \\
\hline NPM & $\mathrm{t}_{\text {hitung }}=1,699$ & 0,101 \\
\hline Regression & $\mathrm{F}_{\text {hitung }}=19,846$ & 0,000 \\
\hline
\end{tabular}

Berdasarkan tabel ringkasan hasil uji hipotesis di atas, $t_{\text {hitung }}$ untuk pengujian parsial antara ROA, NPM dan Perataan Laba masingmasing sebesar 7,615, dan 1,699 dengan nilai sign sebesar 0,219, 0,000 , dan 0,101. Kriteria yang digunakan dalam pengambilan keputusan adalah $\mathrm{H}_{0}$ diterima jika nilai sign $>0,05$ dan $t_{\text {hitung }}>$ dari $t_{\text {tabel. }}$. Nilai $t_{\text {tabel }}$ yang digunakan dalam penelitian ini sebesar
2,00324, maka dapat disimpulkan bahwa hanya variabel ROA yang berpengaruh signifikan secara parsial terhadap perataan laba, sedangkan variable net profit margin tidak berpengaruh signifikan secara parsial terhadap perataan laba.

Berdasarkan tabel ringkasan hasil uji hipotesis di atas, diperoleh $\mathrm{F}_{\text {hitung }}$ untuk pengujian simultan antara ROA dan NPM terhadap perataan laba sebesar 19,846 dengan nilai sign sebesar 0,000 . Nilai $F_{\text {tabel }}$ yang digunakan dalam penelitian ini sebesar 2,78, maka dapat disimpulkan bahwa variabel ROA dan NPM berpengaruh signifikan secara simultan terhadap perataan laba.

\section{Hasil Uji Analisis Regresi Berganda}

Coefficients $^{\mathrm{a}}$

\begin{tabular}{|c|c|c|c|c|c|c|c|}
\hline \multirow[t]{2}{*}{ Model } & \multicolumn{2}{|c|}{$\begin{array}{l}\text { Unstandardized } \\
\text { Coefficients }\end{array}$} & \multirow{2}{*}{\begin{tabular}{|c}
$\begin{array}{c}\text { Standardize } \\
\mathrm{d} \\
\text { Coefficient } \\
\mathrm{s}\end{array}$ \\
Beta
\end{tabular}} & \multirow[t]{2}{*}{$\mathrm{T}$} & \multirow[t]{2}{*}{ Sig. } & \multicolumn{2}{|c|}{$\begin{array}{l}\text { Collinearity } \\
\text { Statistics }\end{array}$} \\
\hline & B & $\begin{array}{l}\text { Std. } \\
\text { Error }\end{array}$ & & & & $\begin{array}{c}\text { Toleranc } \\
\mathrm{e}\end{array}$ & VIF \\
\hline $\begin{array}{l}\text { (Consta } \\
\text { nt) }\end{array}$ & ,066 & ,288 & & ,230 & ,819 & & \\
\hline ROA & 1,624 & ,224 & 697 & 7,238 & ,000 & ,968 & 1,033 \\
\hline NPM & 1,153 & 1,186 & ,095 & ,972 & ,335 & ,936 & 1,068 \\
\hline
\end{tabular}

a. Dependent Variable: DPR

Sumber: Pengolahan data dengan SPSS 21.0

Tabel di atas merupakan hasil pengujian terhadap seluruh variabel penelitian yang bertujuan untuk merumuskan regresi linear berganda.
Perumusan regreasi linear berganda antara Return on Asset dan Net Profit Margin, dan perataan laba adalah sebagai berikut: 
$Y=1,624\left(X_{1}\right)+1,153\left(X_{2}\right)+e$

Berdasarkan hasil persamaan di atas, dapat disimpulkan bahwa:

1. Nilai konstanta sebesar 0,066 , menyatakan bahwa jika tidak ditambah dengan ROA dan NPM maka nilai perataan laba sebesar $0,066(6,6 \%)$.

2. Nilai koefisien regresi atas ROA sebesar 1,624 (162,4\%), menyatakan bahwa setiap penambahan $10 \%$ (sepuluh persen) pada nilai ROA akan meningkatkan nilai perataan laba sebesar $16,24 \%$ (enam belas koma dua puluh empat persen)
3. Nilai koefisien regresi atas NPM sebesar $1,153(115,3 \%)$, menyatakan bahwa setiap penambahan $10 \%$ (sepuluh persen) pada nilai pajak maka akan meningkatkan nilai perataan laba sebesar $11,53 \%$ (sebelas koma lima puluh tiga persen).

Koefisien determinasi digunakan untuk mengetahui kemampuan variabel independen dalam menjelaskan variabel dependen. Berikut ini merupakan hasil uji keofisien determinasi.

Model Summary ${ }^{\text {b }}$

\begin{tabular}{|l|r|r|r|r|r|}
\hline $\begin{array}{l}\text { Mode } \\
1\end{array}$ & $\mathrm{R}$ & $\mathrm{R}$ Square & $\begin{array}{c}\text { Adjusted R } \\
\text { Square }\end{array}$ & $\begin{array}{l}\text { Std. Error of } \\
\text { the Estimate }\end{array}$ & $\begin{array}{c}\text { Durbin- } \\
\text { Watson }\end{array}$ \\
\hline 1 &, $731^{\mathrm{a}}$ &, 534 &, 507 &, 2447647967 & 1,932 \\
\hline
\end{tabular}

a. Predictors: (Constant), NPM, ROA

b. Dependent Variable: PL

Sumber: Pengolahan data dengan SPSS 21.0

Berdasarkan tabel di atas nilai Adjusted $R$ Square sebesar 0,507 $(50,7 \%)$. Hal ini berarti bahwa, variabel independen yang digunakan dalam penelitian ini dapat menjelaskan variabel dependen sebesar $50,7 \%$, sisanya sebesar 49,3\% dijelaskan oleh variabel lain.

\section{SIMPULAN}

\subsection{Simpulan}

Berdasarkan hasil analisis data, maka dapat disimpulkan sebagai berikut:
1. Adanya indikasi perataan laba pada perusahaan manufaktur yang terdaftar di BEI, karena dari 53 Perusahaan yang diteliti 21 perusahaan melakukan praktek perataan laba

2. Tidak terdapat perbedaan yang mencolok dari besaran perusahaan, Return on asset dan net profit margin dari perusahaan yang melakukan perataan laba dengan yang tidak melakukan perataan laba dari segi skala perusahaan

3. Hanya variabel ROA yang berpengaruh signifikan secara parsial 
terhadap perataan laba, sedangkan variabel Net profit margin tidak berpengaruh signifikan secara parsial terhadap perataan laba.

\section{DAFTAR PUSTAKA}

Astuti, Pratiwi Dwi. 2012. Akuntansi Keuangan Dasar 1. Center Foe Academic Publishigs. Yogyakarta.

Berryllian, Diefky. 2007. Analisis FaktorFaktor yang Berpengaruh Terhadap Perataan Laba pada Perusahaan Manufaktur dan Keuangan yang Terdaftar di Bursa Efek Indonesia. Skripsi, Yogjakarta, Universitas Islam Indonesia.

Djarwanto. 2005. Pokok-pokok Analisa Laporan Keuangan. Badan Penerbit Fakultas Ekonomi. Yogyakarta.

Dwiatmini, Sesilia dan Nurkholis. 2001. Analisis Reaksi Pasar Terhadap Informasi Laba: Kasus Praktik Perataan Laba Pada Perusahaan yang Terdaftar di Bursa Efek Indonesia. Tema, vol II no 1, maret

Faisal, M. Abdullah. 2002. Dasar-dasar Manajemen Keuangan (Edisi Kedua). UMM Press. Malang.

Gitman, Lawrence J. 2006. Principles Of Manaherial Finance Eleventh Edition. Pearson Addison Weasly. Boston.

Ghozali, Imam. 2006. Aplikasi Analisis Multivariae dengan Program SPSS. Semarang: Badan Penerbit Universitas Diponegoro

Harahap, Sofyan, Syafi'i. 2004. Teori Akuntansi. Jakarta: Raja Grafindo Persada.

Houston, F, Joel \& Eugene F. Brigham. 2006. Fundamentals of
FinancialManagement. Eight Edition https://www.idx.co.id.

IAI. 2007. Standar Akuntasi Keuangan. Salemba Empat.Indonesian Capital Market Directory 2009, 2010, 2011, 2012, 2013, 2014

Irawati, Zulfa dan Anugerah Maya A. 2007. Analisis Perataan Laba (Income Smooting): Faktor yang Mempengaruhinya dan Pengaruhnya Terhadap Return dan Risiko Saham Perusahaan Go Public di Bursa Efek Indonesia. Benefit, vol 11 no 1, juni

Juniarti dan Corolina. Analisa FaktorFaktor yang Berpengaruh Terhadap Perataan Laba (Income Smooting) Pada PerusahaanPerusahaan Go Public. http://www.petra.ac.id/puslit/journals/dir.php

Masodah. 2007. Praktik Perataan Laba Sektor Industri Perbankan dan LembagaKeuangan Lainnya dan Faktor yang Mempengaruhinya. ISSN: $1858-2559$, vol 2

Ma'ruf, Muhammad. 2009. Analisis Faktor-Faktor yang Mempengaruhi Manajeme Laba pada Perusahaan Go Publik di Bursa Efek Indonesia. Skripsi, Yogjakarta, Universitas Islam Indonesia.

Munawir, S. 2005. Analisa Keuangan. Liberty. Yogyakarta.

Narsa, I Made, Bernadetta Diana Nugraheni dan Benedikta Maritza. 2003. Faktor- Faktor yang Mempengaruhi Praktik perataan laba Selama Krisis Moneter Pada Perusahaan yang Terdaftar di Bursa Efek Surabaya. Majalah Ekonomi XII no 2 
Suwito, Edi dan Arleen Herawaty. 2005. Analisis Pengaruh Karakteristik Perusahaan Terhadap Tindakan Perataan Laba yang Dilakukan oleh Perusahaan yang Terdaftar di Bursa Efek Indonesia. Simposium Nasional Akuntansi VII solo

Suwardjono. 2005. Teori Akuntansi perekayasaan Laporan Keuangan. Edisi ketiga. Yogyakarta, BPFE

Syamsudin, Lukman. 2001. Manajemen Keuangan perusahaan, Konsep Aplikasi dalam Perencanaan, Pengawasan dan Pengambilan Keputusan. PT. Raja Grafindo Persada. Jakarta.

Tudor, A. (2002). Income Smoothing and Earnings Informativeness A matter of institutional characteristics or accounting standards ?, 62-80.

Weston, J Fred dan Eugene F Brigham. 2006. Manajemen Keuangan. Erlangga. Jakarta.

W, Teguh. 2004. Cara Mudah Melakukan Analisa Statistik dengan SPSS. Gava Media: Yogyakarta. http://bilongtuyu.blogspot.co.id/2013/05/ definisi-net-profit-marginnpm.html

https://www.academia.edu/5092831/Inco me_smoothing

https://akuntansiterapan.com/2010/06/16/ perataan-laba/

http://download.portalgaruda.org/article. php?article $=347216 \&$ val $=6468 \&$ tit le

http://www.seputarforex.com/artikel/saha $\mathrm{m} /$ lihat.php?id=207266\&title=peng ertian_net_profit_margin_npm

http://repository.widyatama.ac.id/xmlui/b itstream/handle/123456789/4522/B $\mathrm{ab} \% 201$. df? sequence $=9$

https://www.slideshare.net/heningminoze lfcloudhottes/reaksi-pasar-modalterhadap-laporan-keuangan-teoriakuntansi

http://eprints.ums.ac.id/52063/11/Naskah $\% 20$ Publikasi-ade.pdf

http://rocketmanajemen.com/manajemenlaba/ 